\title{
MMP-7 derived peptides with MHC class-I binding motifs from canine mammary tumor tissue elicit strong antigen-specific T-cell responses in $\mathrm{BALB} / \mathrm{c}$ mice
}

\author{
Pavan Kumar Yadav ${ }^{1,2}$ - Shishir Kumar Gupta ${ }^{1,3} \cdot$ Saroj Kumar ${ }^{1,2} \cdot$ Mayukh Ghosh $^{2} \cdot$ Brijesh Singh Yadav $^{1,4}$. \\ Dinesh Kumar ${ }^{1,5} \cdot$ Ajay Kumar $^{1} \cdot$ Mohini Saini $^{1} \cdot$ Meena Kataria ${ }^{1}$
}

Received: 1 May 2020 / Accepted: 7 September 2020 / Published online: 24 September 2020

(c) Springer Science+Business Media, LLC, part of Springer Nature 2020

\begin{abstract}
Matrix Metalloproteinases (MMPs)-induced altered proteolysis of extracellular matrix proteins and basement membrane holds the key for tumor progression and metastasis. Matrix metalloproteinases-7 (Matrilysin), the smallest member of the MMP family also performs quite alike; thus serves as a potential candidate for anti-tumor immunotherapy. Conversely, being an endogenous tumor-associated antigen (TAA), targeting MMP-7 for immunization is challenging. But MMP-7-based xenovaccine can surmount the obstacle of poor immunogenicity and immunological tolerance, often encountered in TAA-based conventional vaccine for anti-tumor immunotherapy. This paves the way for investigating the potential of MMP-7-derived major histocompatibility complex (MHC)-binding peptides to elicit precise epitope-specific T-cell responses towards their possible inclusion in anti-tumor vaccine formulations. Perhaps it also ushers the path of achieving multiple epitope-based broad and universal cellular immunity. In current experiment, an immunoinformatics approach has been employed to identify the putative canine matrix matelloproteinases-7 (cMMP-7)-derived peptides with MHC class-I-binding motifs which can elicit potent antigen-specific immune responses in BALB/c mice. Immunization with the cMMP-7 DNA vaccine induced a strong $\mathrm{CD} 8^{+}$cytotoxic T lymphocytes (CTLs) and Th1- type response, with high level of gamma interferon (IFN- $\gamma$ ) production in BALB/c mice. The two identified putative MHC-I-binding nonameric peptides (Peptide $32-40$ and Peptide ${ }_{175-183}$ ) from cMMP-7 induced significant lymphocyte proliferation along with the production of IFN- $\gamma$ from $\mathrm{CD} 8^{+} \mathrm{T}$-cells in mice immunized with cMMP-7 DNA vaccine. The current observation has depicted the immunogenic potential of the two cMMP7-derived nonapeptides for their possible exploitation in xenovaccine-mediated anti-tumor immunotherapy in mouse model.
\end{abstract}

Keywords Immunoinformatics $\cdot$ Mammary tumor $\cdot$ Matrix metalloproteinase-7 $\cdot$ Major histocompatibilty complex $\cdot$

Xenogeinic DNA vaccine

Pavan Kumar Yadav

pavanivri2010@gmail.com; pavanivri2010@gmail.com

1 ICAR-Indian Veterinary Research Institute, Izatnagar, Bareilly, Uttar Pradesh 243122, India

2 Faculty of Veterinary and Animal Sciences, Rajiv Gandhi South Campus, Banaras Hindu University, Mirzapur, Uttar Pradesh 231001, India

3 Laboratory Animal Facility, CSIR-CDRI, Lucknow, Uttar Pradesh 226031, India

4 University of Information Science \& Technology St. Paul the apostle Partizanska bb., 6000 Ohrid, Republic of Macedonia

5 College of Agriculture, Tikamgarh, Jawaharlal Nehru Krishi Vishwa Vidylaya, Jabalpur, Madhya Pradesh 482004, India

\section{Introduction}

Cancer stands next to cardiovascular disease as the secondleading cause of global death with an estimated accountability around 9.6 million deaths in 2018 [1]. Among several cancer types, breast cancer is the most common among women, affecting 2.1 million women each year with approximately 627,000 deaths in 2018 which is around $15 \%$ of overall cancer deaths accountability among women [1]. The incidence and mortality rate of breast cancer cases world widely is reported to be $11.6 \%$ and $6.6 \%$, respectively. Further, it has been estimated that the total breast cancer cases per year will be $2,778,850$ in 2040 as per the prediction of World Health Organisation (WHO) [2]. Surgery, radiotherapy and systemic therapy are the major therapeutic modalities to be 
employed alone or in combination considering the available resources and patient factors. For instance, efficacy analyses of chemotherapeutic agents such as doxorubicin and tamoxifen in presence of cholesterol-depleting agent methyl$\beta$-cyclodextrin, and mitomycin $\mathrm{C}$ along with proteasomal inhibitor MG132 has depicted promising outcomes in preclinical models of several solid tumors [3-5]). Regulatory microRNAs (miRNAs)-based therapeutics which regulates key cancer signalling mediators has also yielded promising outcome in breast cancer suppression [6-8]. Several regulatory cytokines of diverse cancer signalling pathways can also serve as novel therapeutic checkpoints in targeted oncotherapy $[9,10]$. Even the herbal products such as bitter melon extract, Ricinus communis L. fruit extract, Scrophularia atropatana extracts, etc. which produced promising results in restricting breast cancer growth in pre-clinical model, has been suggested as potential therapeutic module for cancer treatment [11-14]. However, cancer recurrence or spread along with general cytotoxicity often arises as post-therapeutic complications leading into poor prognosis. Thus, an ideal cancer treatment should have specificity to distinguish neoplastic and healthy cells and the potency to eradicate systemic tumors from the body. In this perspective, antigenspecific anti-angiogenesis and cancer immunotherapy represent two attractive approaches for efficient cancer treatment. The activation of antigen-specific CTL-mediated immune responses induce killing of tumor cells expressing specific tumor associated antigen (TAA) [15-18]; while inhibition of angiogenesis controls neoplastic growth by sequestering the malignant cells from adequate blood supply [19]. Hence, blending of both the approach may serve to elicit the most potent and precise antitumor effect.

Identification and targeting of several key type-specific TAAs have opened the avenue for precise immunotherapy of different tumor types in recent times. Matrix metalloproteinaseses-7 (MMP-7), cognominated as matrilysin is a crucial TAA having plethora of functions for tumor progression and metastasis. MMP-7 induced proteolysis of extracellular matrix (ECM) proteins and basement membrane paves the path for tumorigenic invasion [20-23]. Simultaneous modulation of several cancer signalling pathways related to inflammation, angiogenesis, cell proliferation, apoptosis and migration also produce synergistic effect towards tumor establishment and progression; thus rendering MMP-7 as key target for TAA-based tumor immunotherapy [24-26]. Despite the potential, the most common problem encountered with TAA-based cancer vaccine is most of such antigens are self and predominantly non-mutated proteins of patient's own origin, thus poorly immunogenic as well as oftentimes obstacled by immunological tolerance to elicit significant immune responses [27-29]. Although TAAs are mostly evolutionarily conserved but the subtle interspecies structural variability can be exploited to develop xenovaccines for targeted immunotherapy which can surmount the inherent limitations of TAA-based vaccines. Significant success has been achieved in recent times by introducing such xenogenic homologous TAA proteins to induce potent immune response against their self endogenous counterpart [20-32]. Further xenogenic DNA vaccines can elicit $\mathrm{T}$ cell as well as antibody responses which adds extra edge over conventional autologic and allogenic cell-based vaccines and peptide tumor antigens [33-35]. Although the potency has yet to be a tested in human but xenovaccinotherapy has already achieved laboratory to clinical transition to serve as effective mean for the treatment of melanoma, renal cancer, tumors of digestive system, lung cancer and prostate cancer [36]. The scope of the current strategy can be extended towards customization of polyvalent or chimeric xenogenic cancer vaccines based upon fusion of strongly immunogenic epitopes from a single or multiple TAAs. MMP-7 peptides have been depicted to elicit CTL responses which recognize primary autologous leukemic cells and lyse them in a MHC-restricted and antigenspecific manner but spared normal $\mathrm{B}$ and $\mathrm{T}$ cells [37]. In current elucidation, two nonameric peptides (Peptide ${ }_{32-40}$ and Peptide ${ }_{175-183}$ ) from cMMP-7 with MHC class-I binding motifs were identified. The customized synthetic peptides were evaluated for their ability to induce a CTL response in vitro in $\mathrm{BALB} / \mathrm{c}$ mice primed with the whole protein (cMMP-7 DNA Vaccine).

\section{Materials and methods}

\section{Ethics statement}

The animal experiments performed in the current study, were strictly adhered with the policy on the guidelines and approval of the Institute Animal Ethics Committee (IAEC) and Committee for the Purpose of Control and Supervision of Experiments on Animals (CPCSEA), approval letter No. F. 26-1/2015-16/J.D (R). Mice were euthanized employing $\mathrm{CO}_{2}$, and every measure was extended to minimise the animal suffering.

\section{Cell lines and culture condition}

The HEK-293 T cell line was obtained from The National Centre for Cell Science (NCCS), Pune, India and adopted to grow in DMEM with L-Glutamine $(2 \mathrm{mM}), \mathrm{NaHCO}_{3}$ $(1.5 \mathrm{mM})$ and HEPES (10 $\mathrm{mM})$ buffer (Himedia, India). All cultures were supplemented with $10 \%$ fetal bovine serum (Hyclone, USA) and $50 \mu \mathrm{g} / \mathrm{ml}$ of gentamycin (Gibco; Invitrogen, UK), and were kept in a humidified environment at $37^{\circ} \mathrm{C}$ in the presence of $5 \% \mathrm{CO}_{2}, 95 \%$ air atmosphere. Cells were trypsinized using standard protocol for harvesting. 


\section{Plasmid, construction of DNA vaccines}

MMP-7 gene from canine mammary tumor and murine MMP-7 was cloned in pVIVO2-mcs vector (InvivoGen, USA) for customizing xenogenic MMP-7 DNA vaccine constructs. The constructs were found to be functionally active as reported in our previous study $[38,39]$. The recombinant pVIVO2.cMMP-7, pVIVO2.mMMP-7 and pVIVO2 vector were purified using EndoFree Plasmid Mega Kit (Qiagen, Germany) as per manufacture's protocol, and purified products were re-suspended in normal saline followed by quantification using NanoDrop ${ }^{\mathrm{TM}} 1000$ Spectrophotometer (Thermo Scientific, USA).

\section{Experimental mice and immunization}

The female Balb/c mice of about 4-5 weeks were purchased from National Centre for Laboratory Animal Sciences, Hyderabad, India. The animals were maintained at the Division of Biochemistry, Indian Veterinary Research Institute India. Mice were kept in well-fumigated house and polypropylene cages following strict hygienic measures under standard feeding and watering management [40]. In this study, three experimental groups were included viz. I (pVIVO2.mcs), II (pVIVO2.mMMP-7) and III (pVIVO2.cMMP-7) for immunization with respective DNA vaccine. Each group contained six mice which were inoculated intramuscularly with $100 \mu \mathrm{g}$ of respective plasmid DNA and boosted with the same amount of DNA construct on days 14 and 28. Sera and splenocytes were collected 1 week after the last immunization. Vaccination with empty pVIVO2 vector served as the control.

\section{Antigens and synthetic peptides}

The full-length cMMP-7 was cloned into pET32a expression vector melded to a histidine (His) tag using primer pair 5'-CAGGATCCCAGGTCAGGACTATCTC-3' and 5'-GCCGAAGCTTAAATTCTGT TCCCTCCGTATA-3'. The His-tagged recombinant protein was expressed in $E$. coli BL21 (DE3) and purified by Ni-NTA chromatography, as described previously [41]. The in-silico analyses of cMMP-7 protein sequence for identification of putative high-affinity binding nonapeptides with class I HLA and class I mouse MHC was performed using BIMAS [42] and SYFPEITHI [43] algorithms. The predictive analyses yielded two most eligible cMMP-7 derived peptides containing MHC class I-restricting motifs, ${ }^{32}$ FFRLPVTGI ${ }^{40}$ (Peptide $_{32-40}$ ) and ${ }^{175}$ FLIAATHEL $^{183}$ (Peptide ${ }_{175-183}$ ) which were custom synthesized (Hysel, India). The customized peptides were dissolved in distilled water to achieve a concentration of $10 \mu \mathrm{g} / \mathrm{ml}$ and stored at $-70{ }^{\circ} \mathrm{C}$ till further use.

\section{Quantification of $\lg G 1$ and $\lg$ G2a isotypes by ELISA}

Serum IgG1 and IgG2a concentrations from the vaccinated animals after seven days of the last immunization were estimated in triplicate using an ELISA kit (eBioscience, USA) according to the manufacturer's guidelines.

\section{Lymphocyte transformation test (LTT) employing 3-(4,5 dimethylthiazol-2-yl)-2,5-diphenyl tetrazolium bromide (MTT) assay}

Antigenic-specific multiplication of mice splenocytes was analysed by lymphocyte proliferation assay [44]. Briefly, at the seventh day after the last immunization, spleens from the mice were dissected out and disintegrated with a glass slide. The splenocytes were strained using a cell strainer $(40 \mu \mathrm{M}$, BD Falcon, USA) and treated with $0.75 \%$ ammonium chloride buffer ( $\mathrm{pH} 7.65$ ) for $5 \mathrm{~min}$ to lyse red blood cells. The splenocytes $\left(2 \times 10^{6} / \mathrm{ml}\right)$, were resuspended into RPMI1640 medium supplemented with $2 \mathrm{mM} \mathrm{L}$-glutamine, $10 \%$ heat inactivated FCS, $50 \mathrm{U} / \mathrm{ml}$ penicillin, and $50 \mathrm{U} / \mathrm{ml}$ streptomycin. The cell suspensions $(100 \mu \mathrm{l})$ were plated in triplicate, each for stimulated and un-stimulated control in 96-well culture plate and incubated with $10 \mu \mathrm{g} / \mathrm{ml}^{32}$ FFRLPVTGI ${ }^{40}$ (Peptide ${ }_{32-40}$ ) and ${ }^{175}$ FLIAATHEL ${ }^{183}$ (Peptide ${ }_{175-183}$ ) under $\mathrm{IL}-2(20 \mathrm{IU} / \mathrm{ml})$ stimulation for $72 \mathrm{~h}$ at $37^{\circ} \mathrm{C}$ with $5 \% \mathrm{CO}_{2}$. The MTT solution $(20 \mu \mathrm{l}$ at $5 \mathrm{mg} / \mathrm{ml}$ concentration) was added to each well and the plate was incubated for another $4 \mathrm{~h}$ at $37^{\circ} \mathrm{C}$. Subsequently the plate was centrifuged at $400 \mathrm{~g}$ for $10 \mathrm{~min}$ to discard the supernatant followed by addition of $150 \mu \mathrm{LMSO}$ and thorough mixing by pipetting. The solubilisation of formazan crystals was visualized under microscope and finally absorbance was recorded at $595 \mathrm{~nm}$ with iMark $^{\mathrm{TM}}$ Microplate Absorbance Reader (Bio-Rad, USA).

\section{Intracellular cytokine staining with flow cytometry analysis to detect CD8 + IFN- $\gamma+\mathrm{T}$-cells}

Seven days after the last immunization mice splenocytes were suspended $\left(2 \times 10^{6} / \mathrm{ml}\right)$ in supplemented RPMI1640 medium containing $2 \mathrm{mM} \mathrm{L-glutamine,} 10 \%$ inactivated FBS, $50 \mathrm{U} / \mathrm{ml}$ penicillin, and $50 \mathrm{U} / \mathrm{ml}$ streptomycin. The cell suspensions $(100 \mu \mathrm{l})$ were plated in 96 -well culture plate (in triplicate) and incubated with $10 \mu \mathrm{g} / \mathrm{ml}^{32}{ }^{3}$ FRLPVTGI ${ }^{40}$ $\left(\right.$ Peptide $\left._{32-40}\right) /{ }^{175}$ FLIAATHEL $^{183}$ (Peptide ${ }_{175-183}$ ) under IL-2 (20 IU/ml) stimulation for $72 \mathrm{~h}$ at $37{ }^{\circ} \mathrm{C}$ with $5 \% \mathrm{CO}_{2}$. Then Brefeldin A (10 $\mu \mathrm{g} / \mathrm{ml}$; Sigma, USA) was added and incubated further for another $6 \mathrm{~h}$. The cells were washed with RPMI 1640 by centrifugation at $350 \times g$ for $5 \mathrm{~min}$ and stained for surface CD8 molecules and intracellular INF- $\gamma$ 
using conjugated mAbs [45]. Cells were stained for CD8 with FITC-conjugated rat anti-mouse CD8a mAbs (clone 53-6.7; eBioscience, USA) by adding $0.4 \mu \mathrm{g}$ of each antibody for $1 \times 10^{6}$ cells, followed by incubation at room temperature for $30 \mathrm{~min}$. Surface-stained cells were washed twice with washing solution $(0.2 \%$ BSA and $0.2 \%$ sodium azide in PBS) and fixed with $4 \%$ paraformaldehyde at $4{ }^{\circ} \mathrm{C}$ for $15 \mathrm{~min}$. Furthermore, the cells were permeabilized with $0.1 \%$ saponin (Sigma, USA) at $37{ }^{\circ} \mathrm{C}$ for $15 \mathrm{~min}$ followed by washing with $0.1 \%$ saponin buffer before staining for intracellular INF- $\gamma$ with PE-Cy5-conjugated rat anti-mouse INF- $\gamma$ mAb (Southern Biotech, USA) at $37^{\circ} \mathrm{C}$ for $30 \mathrm{~min}$. At last, the cells were washed thrice with washing buffer, fixed with $1 \%$ paraformaldehyde and stored at $4{ }^{\circ} \mathrm{C}$ until analysis by flow cytometry. The predicted frequency of CD $8+$ INF- $\gamma+$ T-cells was determined by subtracting the percentage of unsensitized CD8 $+\mathrm{INF}-\gamma+\mathrm{T}$ - cells from the percentage of antigen-sensitized CD $8+\mathrm{INF}-\gamma+\mathrm{T}$ - cells.

\section{Statistical analysis}

The data were subjected to analyses of variance (ANOVA) using the SPSS statistical package (SPSS for Windows 20 software). Differences among the data sets were tested with one-way ANOVA Duncan's multiple range tests, and $p<0.05$ was considered as level of significance.

\section{Results}

\section{Cloning of cMMP-7 gene, expression and purification of recombinant CMMP-7 protein}

The amplified cMMP-7 gene fragment was cloned into pET32a expression vector and transformed into E. coli DH5 $\alpha$ cells. Plasmids were isolated from the selected colonies and checked for the insert releasing by RE double digestion with
EcoRI and HindIII. The recombinant plasmids released a 691 bp insert of desired size (Fig. 1a). The cMMP-7 mature peptide was recombinantly expressed in E. coli BL21(DE3) as a fusion protein with $6 \mathrm{XHis}$ tag having about $43.7 \mathrm{kDa}$ (Fig. 1b) size. The specific reactivity of the Ni-NTA affinity purified recombinant protein was verified by western blotting (Fig. 1c) using rabbit anti-cMMP-7 hyperimmune sera available in the laboratory. The $\mathrm{H} 2 \mathrm{~K}^{\mathrm{d}}$ prediction analysis indicated that canine MMP- $7{ }^{32}$ FFRLPVTGI $^{40}\left(\right.$ Peptide $\left._{32-40}\right)$ and ${ }^{175}$ FLIAATHEL ${ }^{183}$ (Peptide ${ }_{175-183}$ ) possessed significant binding affinity as high-scoring MHC class I $\left(\mathrm{H} 2 \mathrm{~K}^{\mathrm{d}}\right)$ epitopes as compared to the other remaining peptides.

\section{Antibodies responses in immunized mice}

Mice from the cMMP-7 vaccinated group generated significantly higher levels of IgG antibody titer in comparison to the other vaccinated groups [39]. IgG subtype analyses indicated towards the type of immune response elicited by the DNA vaccine. The IgG1 and IgG2a subtype antibody levels in all the groups after seven days of the final immunization were depicted in the Fig. 2. Mice immunized with pVIVIO2.cMMP-7 DNA vaccine generated significantly $(p<0.05)$ higher levels of $\operatorname{IgG} 1(1166 \pm 68.00 \mu \mathrm{g} / \mathrm{ml})$ and IgG2a $(373.1 \pm 19.20 \mu \mathrm{g} / \mathrm{ml})$ response in respect to the other two vaccinated groups: pVIVO2.mMMP-7 (IgG1: $233.85 \pm 30.15 \mu \mathrm{g} / \mathrm{ml}$ and IgG2a: $129.55 \pm 2.55 \mu \mathrm{g} / \mathrm{ml}$ ) or pVIVO2mcs vector control (IgG1: $281.9 \pm 16.50 \mu \mathrm{g} / \mathrm{ml}$ and IgG2a: $120.05 \pm 1.95 \mu \mathrm{g} / \mathrm{ml})$. All the data were presented as Mean \pm SEM.

\section{Lymphocyte proliferation assay}

Lymphocyte proliferation assay demonstrated the T-lymphocyte proliferation indicating the cellular immune responses. The pVIVO2.cMMP-7 vaccinated group of mice showed significantly $(p<0.01)$ higher stimulation index in presence
Fig. 1 Cloning of canine MMP-7 (cMMP-7), Purification of recombinant cMMP-7 and Western blotting a Double endonuclease digestion of the recombinant vector $\mathrm{pET}-32 \mathrm{a}$. cMMP-7: M-DNA maker; Lane 1: Undigested recombinent plasmide and lane 2- release of insert, digestion with EcoR1 and Hindlll $\mathbf{b}$ SDS-PAGE of purified r-cMMP-7 protein c Western blot of rMMP-7 by using Polyclonal antiserum raised against r-cMMP-7: Mprotein ladder, lane 1- immunoblot at $43.7 \mathrm{kDa}$
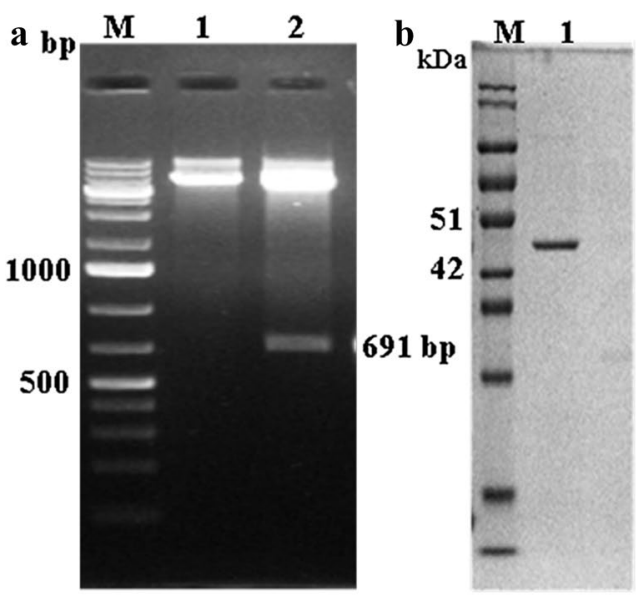

$43.7 \mathrm{kDa}$

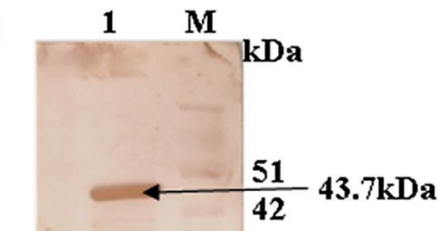




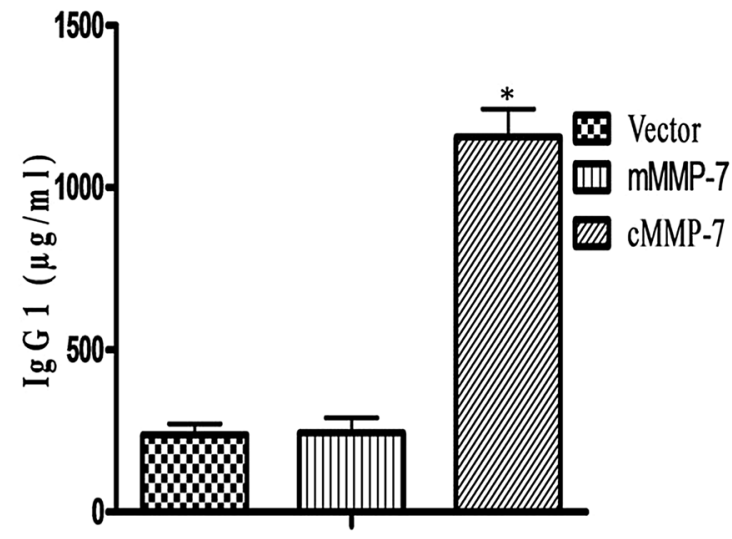

Fig. 2 Antibody isotyping secretion in BALB/c mice immunized with cMMP-7: Bar diagram showing effect of treatment on immunoglobulin and presented as Mean \pm SEM diagram. Significant difference

of recombinant-cMMP-7 as well as both the cMMP-7 derived peptides, ${ }^{32}$ FFRLPVTGI $^{40}$ (Peptide ${ }_{32-40}$ ) and ${ }^{175}$ FLIAATHEL $^{183}$ (Peptide ${ }_{175-183}$ ); whereas no significant difference was observed between the pVIVO2.mMMP-7 and pVIVO2 empty vector control groups (Fig. 3).

\section{Antigen-specific proliferation and INF- $\gamma$ production by cMMP-7-specific T-cell lines}

Seven days after the last vaccination, splenocytes from each group were incubated with cMMP-7 derived peptides, ${ }^{32}$ FFRLPVTGI $^{40}$ (Peptide ${ }_{32-40}$ ) and ${ }^{175}$ FLIAATHEL $^{183}$ (Peptide ${ }_{175-183}$. The percentage of antigen-specific IFN- $\gamma$ producing $\mathrm{CD} 8+\mathrm{T}$-cells following immunization with different DNA vaccines were depicted in Fig. 4a, b. Immunization with canine MMP-7 based xenogeneic DNA vaccine significantly $(P<0.05)$ increased antigen-specific IFN- $\gamma$ producing $\mathrm{CD} 8+\mathrm{T}$-cells in primed splenocytes as compared to

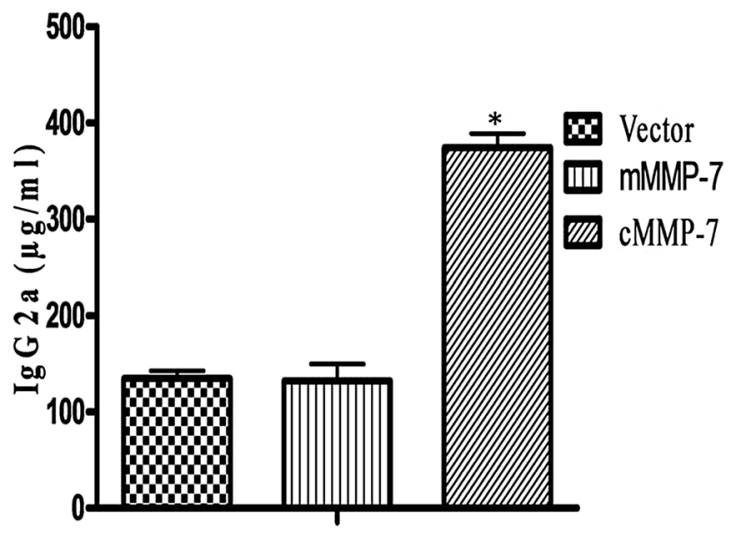

was observed between treated and vector control. However effect of treatment was not differing from the control. $* p<0.05$, level of significance

both pVIVO2.mMMP-7 and pVIVO2 empty vector control groups.

\section{Discussion}

Xenovaccine-mediated immunotherapy is ushering the path for a paradigm shift in oncotherapy from the conventional approaches towards a target-specific safe option alleviating the issues of resistance and general cytotoxicity inherent to chemotherapy. The strategy employing cMMP-7 as TAA have already seemed to untie the knots of poor immunogenicity, tumor induced immunosupression and immunological tolerance to elicit strong NK activity, CTL responses along with up-regulating $\mathrm{Th} 1$ cytokine production in the murine breast cancer model which reduced the tumor growth and increased the survival of the diseased mice. The experiment employed whole recombinant cMMP-7 protein
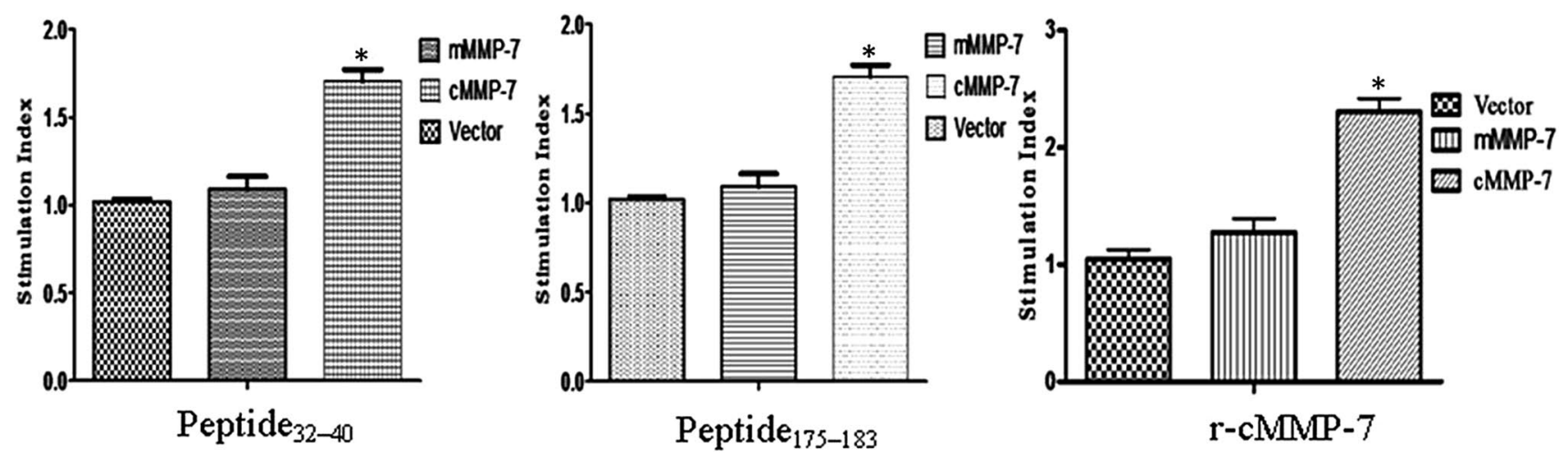

Fig. 3 In vitro T cell proliferative response specific for the cMMP-7 protein and peptides: cMMP-7 DNA primed splenocytes were restimulated in vitro with r-cMMP-7 protein $(20 \mu \mathrm{g} / \mathrm{ml})$ and chosen syn- thetic peptides (Peptide ${ }_{32-40}$ and Peptide ${ }_{175-183}$ ) respectively with concentration of $(10 \mu \mathrm{g} / \mathrm{ml})$ and tested for T-cell proliferation. Results are presented as Mean \pm SEM. $* p<0.01$, level of significance 

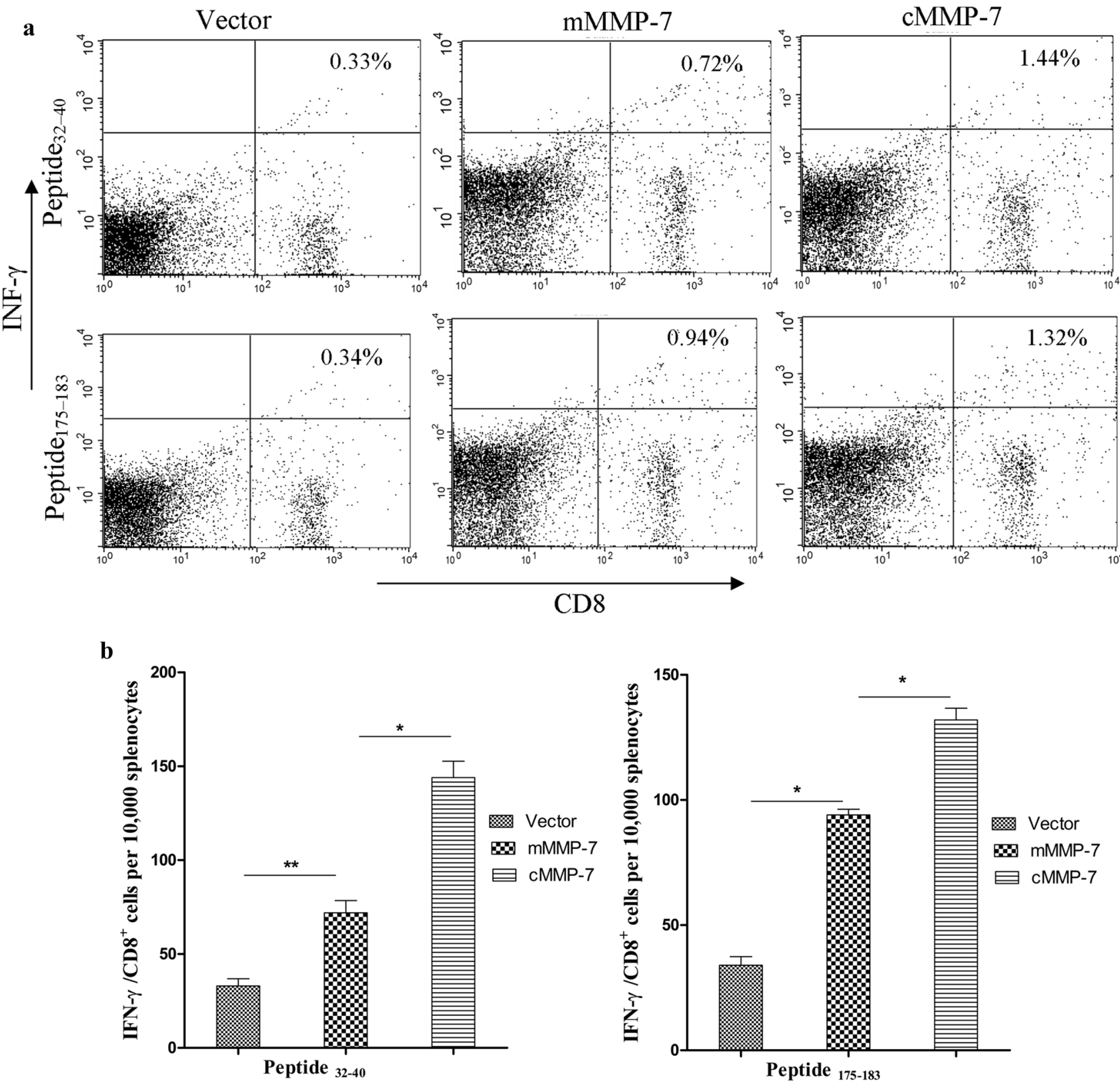

Fig. 4 Expression of IFN- $\gamma$ from stimulated CD8+BALB/c splenocytes: a Intracellular IFN- $\gamma$ staining of antigen-specific $\mathrm{T}$ cells following in vitro stimulation with synthetic peptides. Primed T cells were expended in vitro in the presence of the synthetic peptide $(10 \mu \mathrm{g} / \mathrm{ml})$ and percentage of CD8 $+\mathrm{T}$ cells secreting IFN- $\gamma$ was

for inducing the immune system of the mice vaccinated with pVIVO2.cMMP7 plasmid alone or co-administration with pVIVO2.IL-18 plasmid [39]. Similar approach has yielded success as evidenced by xenogeneic vaccine plasmid DNA encoding human tyrosinase initiated an immune response against the TAA tyrosinase [46]. Several reports depicting the efficacy of xenogeneic vaccines using different TAAs in mouse models also second the concept, such determined by intracellular staining of IFN- $\gamma$, $\mathbf{b}$ Bar diagram showing $\mathrm{IFN}-\gamma / \mathrm{CD} 8+$ cells per 10,000 splenocytes presented as Mean \pm SEM, mice vaccinated with cMMP-7 showed a marked increase in IFN- $\gamma$ / $\mathrm{CD} 8+$ cells compared to the control groups $(* p<0.05)$

as telomerase reverse transcriptase [47], human $\mathrm{N}^{\prime}$-terminal neu DNA vaccine [48], human tumor endothelial marker 8 DNA vaccine [49], and prostatic acid phosphatase dendritic cell-based vaccine [50]. However, further introspection was required to justify that instead of the entire recombinant xenoantigen, whether certain immunodominant peptide can serve the purpose. Fusion of multiple such immunodominant epitopes from a single or multiple TAA scan create 
the avenue for the development of polyvalent or chimeric xenogenic cancer vaccines. In current study, an immunoinformatics approach have been employed to identify cMMP-7 derived peptides with high-affinity MHC class-I binding motifs which can elicit potent antigen-specific T-cell responses in BALB/c mice because an effective vaccine against malignant tumor should enhance cellular immune response, mediated by induction of IFN- $\gamma$ secreting cells and $\mathrm{CD} 8^{+}$CTLs [51]. Several studies have revealed that MHC class I-restricted CD $8+\mathrm{T}$ cells recognise cancerous cells and release IFN- $\gamma$, which kills the cancerous cells, although engagement of both innate as well as adaptive arms of immune system may be indispensable to achieve sustainable tumor regression in metastatic cases [52, 53]. In the present work, we used two of these identified putative T-cell epitopes (Peptide $32-40$ and Peptide ${ }_{175-183}$ ) from the cMMP-7 protein and demonstrated that they were recognized by $\mathrm{CD}^{+} \mathrm{T}$ cells from cMMP-7 DNA-immunized mice. Previously, we observed that vaccination utilizing the xenogeneic cMMP-7 naked DNA vaccine via intramuscular route generated a robust antibody response against mMMP-7 protein. These anti-cMMP-7 antibodies were found to be both highly abundant and specific in comparison to vector and mMMP-7 controls. Further, the vaccine also induced cellular immune responses as evidenced by significant lymphocyte proliferation, immunoglobulin secretions and T-cytotoxic lymphocyte responses in BALB/c mice; thus, proving the potential of cMMP-7 as an effective candidate against mammary tumor [39].

The pVIVIO2.cMMP-7 DNA vaccine induced profound antibody response in the vaccinated animals. The IgG subtype analyses depicted significantly $(p<0.05)$ higher levels of IgG1 and IgG2a levels in cMMP-7 vaccinated animals as compared to the other two groups indicating towards a cMMP-7 DNA vaccine-induced mixed type of Th1/Th2 immune response. In-vitro restimulation of the isolated splenocytes from the mice immunized with pVIVO2. cMMP-7 DNA vaccine with either purified whole recombinant cMMP-7 protein or the customized cMMP-7 derived synthetic peptides depicted that the peptides as well as the intact recombinant protein induced substantial lymphocyte proliferation as significantly $(p<0.01)$ higher stimulation index was observed in presence of recombinant cMMP-7 protein and both of the derived peptides in cMMP-7 vaccinated group only. This indicated antigen-specific clonal expansion of a sub-set of immune cells towards initiation of the specific immune responses in the vaccinated animals. Further, antigen-specific proliferation of IFN- $\gamma^{+} \mathrm{T}$-cells and $\mathrm{CD} 8^{+}$-IFN- $\gamma^{+}$T-cells in primed splenocytes along with enhanced IFN- $\gamma$ production in presence of both the peptides only in cMMP-7 vaccinated group clearly depicted that the cMMP-7 derived putative MHC I binding peptides were successful to mimic the in-vivo natural processing of
c-MMP-7 and its subsequent presentation to elicit a Th1polarized response. The preferential induction of Th1-type cytokines is interesting as this may lead to the activation of macrophages and natural killer cells to execute the cancerous cells selectively, and may also promote the activation and proliferation of antigen specific $\mathrm{CD} 8^{+} \mathrm{CTLs}[54,55]$. The potential of the cMMP-7 derived peptides may be exploited to generate epitope-based xenovaccines for anti-tumor immunotherapy. Perhaps it may facilitate the exploitation of advantages associated with synthetic peptide-based vaccines over entire antigen-based vaccines such as easy packaging in smaller delivery vehicles, possibility of achieving multiple epitope-based broad and universal cellular immunity, etc. in future.

Although, the cMMP-7 epitope-based xenovaccine has yielded promising outcome, however elucidation of the potential immunotoxic effects urges further introspection. The adverse-effects of anti-MMP-7 immunotherapy is yet to be elucidated vividly but human MMP-9 and MMP-2 derived synthetic peptide-based vaccine has significantly restricted tumor growth in mice melanoma without producing any pathological side-effects [56]. Further, peptidebased vaccine immunotherapy targeting several TAAs has also depicted promising outcomes against urological and colorectal cancer without producing any severe adverse effects [57-59]. In contrast, T-cell immunotherapy using engineered $\mathrm{T}$ cell receptor targeted against carcinoembryonic antigen produced significant regression of metastatic colorectal cancer but also induced severe colitis [60]. Thus, a keen attention is required to ensure the safety profile of such vaccines. The adverse effects of the vaccine in pregnancy also requires further investigation as inhibition of MMPs may affect uterine growth and expansion leading to premature labor [61]. However, oral delivery of anti-angiogenic listeriolysin-mVEGFR2 DNA vaccine targeting the VEGF receptor which carries out important functions in peri-implantation angiogenesis during early pregnancy has produced no adversity in establishment and progression of healthy pregnancy $[62,63]$.

\section{Conclusion}

In conclusion, the present introspection has vividly depicted that the putative cMMP-7 derived MHC class I binding nonapeptides have the potential to mimic its corresponding whole antigen counterpart in terms of in-vivo customary antigen processing and presentation to elicit a Th1-polarized response. Considering the xenoantigenic potential of cMMP7 , the acquired knowledge can be replicated to customize single or multiple epitope-based chimeric xenovaccines towards targeted tumor immunotherapy. 
Acknowledgements The authors are thankful to the Director, ICARIndian Veterinary Research Institute Izatnagar-243122, UP, India for providing necessary facilities and providing fund (Grant No. IVRI/ BIOCHEM/11-14/003) to carry out the work.

\section{Compliance with ethical standards}

Conflict of interest Authors declare they have no conflicts of interest.

\section{References}

1. https://www.who.int/news-room/fact-sheets/detail/cancer (12/09/ 2018)

2. https://www.paho.org/hq/index.php/global-cancer-profile (2020)

3. Mohammad N, Malvi P, Meena AS et al (2014) Cholesterol depletion by methyl- $\beta$-cyclodextrin augments tamoxifen induced cell death by enhancing its uptake in melanoma. Mol Cancer 13:204. https://doi.org/10.1186/1476-4598-13-204

4. Mohammad N, Singh SV, Malvi P et al (2015) Strategy to enhance efficacy of doxorubicin in solid tumor cells by methyl$\beta$-cyclodextrin: Involvement of p53 and Fas receptor ligand complex. Sci Rep 5:11853. https://doi.org/10.1038/srep11853

5. Singh SV, Ajay AK, Mohammad N et al (2015) Proteasomal inhibition sensitizes cervical cancer cells to mitomycin $\mathrm{C}$-induced bystander effect: the role of tumor microenvironment. Cell Death Dis 6:e1934. https://doi.org/10.1038/cddis.2015.292

6. Muhammad N, Bhattacharya S, Steele R, Ray RB (2016) AntimiR-203 suppresses ER-positive breast cancer growth and stemness by targeting SOCS3. Oncotarget 7:58595-58605. https ://doi.org/10.18632/oncotarget.11193

7. Rivas MA, Venturutti L, Huang YW, Schillaci R, Huang TH, Elizalde PV (2012) Downregulation of the tumor-suppressor miR-16 via progestin-mediated oncogenic signaling contributes to breast cancer development. Breast Cancer Res 14:R77. https:// doi.org/10.1186/bcr3187

8. Jiang CF, Shi ZM, Li DM et al (2018) Estrogen-induced miR196a elevation promotes tumor growth and metastasis via targeting SPRED1 in breast cancer. Mol Cancer 17:83. https://doi. org/10.1186/s12943-018-0830-0

9. Singh S, Chouhan S, Mohammad N, Bhat MK (2017) Resistin causes G1 arrest in colon cancer cells through upregulation of SOCS3. FEBS Lett 591:1371-1382. https://doi. org/10.1002/1873-3468.12655

10. Kawaguchi K, Sakurai M, Yamamoto Y et al (2019) Alteration of specific cytokine expression patterns in patients with breast cancer. Sci Rep 9:2924. https://doi.org/10.1038/s41598-019-39476-9

11. Muhammad N, Steele R, Isbell TS, Philips N, Ray RB (2017) Bitter melon extract inhibits breast cancer growth in preclinical model by inducing autophagic cell death. Oncotarget 8:6622666236. https://doi.org/10.18632/oncotarget.19887

12. Shim SH, Sur S, Steele R et al (2018) Disrupting cholesterol esterification by bitter melon suppresses triple-negative breast cancer cell growth. Mol Carcinog 57:1599-1607. https://doi.org/10.1002/ mc. 22882

13. Majumder M, Debnath S, Gajbhiye RL et al (2019) Ricinus communis L. fruit extract inhibits migration/invasion, induces apoptosis in breast cancer cells and arrests tumor progression in vivo. Sci Rep 9:14493. https://doi.org/10.1038/s41598-019-50769-x

14. Safarzadeh E, Delazar A, Kazemi T et al (2017) The cytotoxic and apoptotic effects of scrophularia atropatana extracts on human breast cancer cells. Adv Pharm Bull 7:381-389. https:// doi.org/10.15171/apb.2017.046
15. Chung MA, Luo Y, O'Donnell M et al (2003) Development and preclinical evaluation of a Bacillus Calmette-Guérin-MUC1-based novel breast cancer vaccine. Cancer Res 63:1280-1287

16. Disis ML, Schiffman K, Guthrie K, Salazar LG, Knutson KL, Goodell V, de la Rosa C, Cheever MA (2004) Effect of dose on immune response in patients vaccinated with an her-2/neu intracellular domain protein-based vaccine. J Clin Oncol 22:19161925. https://doi.org/10.1200/JCO.2004.09.005

17. Lladser A, Ljungberg K, Tufvesson H, Tazzari M, Roos AK, Quest AF, Kiessling R (2010) Intradermal DNA electroporation induces survivin-specific CTLs, suppresses angiogenesis and confers protection against mouse melanoma. Cancer Immunol Immunother 59:81-92. https://doi.org/10.1007/s00262-009-0725-4

18. Stauss HJ, Thomas S, Cesco-Gaspere M, Hart DP, Xue SA, Holler A, King J, Wright G, Perro M, Pospori C, Morris E (2008) WT1specific T cell receptor gene therapy: improving TCR function in transduced T cells. Blood Cells Mol Dis 40:113-116. https://doi. org/10.1016/j.bcmd.2007.06.018

19. Lu L, Luo ST, Shi HS, Li M, Zhang HL, He SS, Liu Y, Pan Y, Yang L (2012) AAV2-mediated gene transfer of VEGF-Trap with potent suppression of primary breast tumor growth and spontaneous pulmonary metastases by long-term expression. Oncol Rep 28:1332-1338. https://doi.org/10.3892/or.2012.1915

20. Bonnans C, Chou J, Werb Z (2014) Remodelling the extracellular matrix in development and disease. Nat Rev Mol Cell Biol 15:786-801. https://doi.org/10.1038/nrm3904

21. Klein T, Bischoff R (2011) Physiology and pathophysiology of matrix metalloproteases. Amino Acids 41:271-290. https://doi. org/10.1007/s00726-010-0689-x

22. Pittayapruek P, Meephansan J, Prapapan O, Komine M, Ohtsuki M (2016) Role of matrix metalloproteinases in photoaging and photocarcinogenesis. Int J Mol Sci 17:868. https://doi. org/10.3390/ijms 17060868

23. Shiomi T, Lemaître V, D’Armiento J, Okada Y (2010) Matrix metalloproteinases, a disintegrin and metalloproteinases, and a disintegrin and metalloproteinases with thrombospondin motifs in non-neoplastic diseases. Pathol Int 60:477-496. https://doi.org /10.1111/j.1440-1827.2010.02547.x

24. Ii M, Yamamoto H, Adachi Y, Maruyama Y, Shinomura Y (2006) Role of matrix metalloproteinase-7 (matrilysin) in human cancer invasion, apoptosis, growth, and angiogenesis. Exp Biol Med 231:20-27. https://doi.org/10.1177/153537020623100103

25. Ishikawa T, Kimura Y, Hirano H, Higashi S (2017) Matrix metalloproteinase-7 induces homotypic tumor cell aggregation via proteolytic cleavage of the membrane-bound Kunitz-type inhibitor HAI-1. J Biol Chem 292:20769-20784. https://doi.org/10.1074/ jbc.M117.796789

26. Yuan S, Lin L, Gan R et al (2020) Elevated matrix metalloproteinase 7 expression promotes the proliferation, motility and metastasis of tongue squamous cell carcinoma. BMC Cancer 20:33. https ://doi.org/10.1186/s12885-020-6521-4

27. Itoh K, Yamada A, Mine T, Noguchi M (2009) Recent advances in cancer vaccines: an overview. Jpn J Clin Oncol 39:73-80. https ://doi.org/10.1093/jjco/hyn132

28. Slingluff CL Jr, Speiser DE (2005) Progress and controversies in developing cancer vaccines. J Transl Med 3:18-26. https://doi. org/10.1186/1479-5876-3-18

29. Kochenderfer JN, Gress RE (2007) A comparison and critical analysis of preclinical anticancer vaccination strategies. Exp Biol Med 232:1130-1141. https://doi.org/10.3181/0702-MR-42

30. Bergman PJ, Camps-Palau MA, McKnight JA et al (2006) Development of a xenogeneic DNA vaccine program for canine malignant melanoma at the Animal Medical Center. Vaccine 24:45824585. https://doi.org/10.1016/j.vaccine.2005.08.027

31. Walters JN, Ferraro B, Duperret EK et al (2017) A novel DNA vaccine platform enhances neo-antigen-like $\mathrm{T}$ cell responses 
against WT1 to break tolerance and induce anti-tumor immunity. Mol Ther 25:976-988. https://doi.org/10.1016/j.ymthe .2017.01.022

32. Potebnya GP, Symchych TV, Lisovenko GS (2010) Xenogenic cancer vaccines. Exp Oncol 32:61-65

33. Srinivasan R, Wolchok JD (2004) Tumor antigens for cancer immunotherapy: therapeutic potential of xenogeneic DNA vaccines. J Transl Med 2:12. https://doi.org/10.1186/1479-5876-2-12

34. Seledtsov VI, Shishkov AA, Surovtseva MA et al (2006) Xenovaccinotherapy for melanoma. Eur J Dermatol 16:655-661

35. Seledtsov VI, Niza NA, Felde MA, Shishkov AA, Samarin DM, Seledtsova GV, Seledtsov DV (2007) Xenovaccinotherapy for colorectal cancer. Biomed Pharmacother 61:125-130. https://doi. org/10.1016/j.biopha.2006.09.016

36. Seledtsovaa GV, Shishkova AA, Kaschenkoa EA, Seledtsovb VI (2016) Xenogeneic cell-based vaccine therapy for colorectal cancer: safety, association of clinical effects with vaccine-induced immune responses. Biomed Pharmacother 83:1247-1252. https ://doi.org/10.1016/j.biopha.2016.08.050

37. Yokoyama Y, Grünebach F, Schmidt SM, Heine A, Häntschel M, Stevanovic S, Rammensee HG, Brossart P (2008) Matrilysin (MMP-7) is a novel broadly expressed tumor antigen recognized by antigen-specific T cells. Clin Cancer Res 14:5503-5511. https ://doi.org/10.1158/1078-0432.CCR-07-4041

38. Yadav PK, Gupta SK, Kumar S, Saini M, Mishra SR, Nandakumar P, Katari M (2017) Characterization and in vitro expression studies of a potential xenogeneic DNA vaccine against canine mammary tumours. Indian J Anim Sci 87:1480-1484

39. Yadav PK, Gupta SK, Kumar S, Ghosh M, Yadav BS, Kumar D, Kumar A, Saini M, Katari M (2020) IL-18 immunoadjuvanted xenogeneic canine MMP-7 DNA vaccine overcomes immune tolerance and supresses the growth of murine mammary tumor. Int Immunopharmacol 82:106370. https://doi.org/10.1016/j.intim p. 2020.106370

40. National Research Council (US) Committee for the update of the guide for the care and use of laboratory animals (2011) Guide for the care and use of laboratory animals, 8th edn. National Academies Press (US), Washington, D.C.

41. Yadav PK, Sunil Kumar BV, Chanu VKh, Yadav BS, Kumar A, Kataria M (2015) Recombinant tissue inhibitor of metelloproteinase-3 from canine mammary tumor induces apoptosis in-vitro. Indian J Anim Sci 85:588-592

42. Parker KC, Bednarek MA, Coligan JE (1994) Scheme for ranking potential HLA-A2 binding peptides based on independent binding of individual peptide side-chains. J Immunol 152:163-175

43. Rammensee H, Bachmann J, Emmerich NP, Bachor OA, Stevanovic S (1999) SYFPEITHI: database for MHC ligands and peptide motifs. Immunogenetics 50:213-219. https://doi. org/10.1007/s002510050595

44. Sawant PM, Verma PC, Subudhi PK, Chaturvedi U, Singh M, Kumar R, Tiwari AK (2011) Immunomodulation of bivalent Newcastle disease DNA vaccine induced immune response by codelivery of chicken IFN- $\gamma$ and IL-4 genes. Vet Immunol Immunopathol 144:36-44. https://doi.org/10.1016/j.vetimm.2011.07.006

45. Chaitra MG, Shaila MS, Nayak R (2008) Characterization of T-cell immunogenicity of two PE/PPE proteins of Mycobacterium tuberculosis. J Med Microbiol 57:1079-1086. https://doi. org/10.1099/jmm.0.47565-0

46. Grosenbaugh DA, Leard AT, Bergman PJ et al (2011) Safety and efficacy of a xenogeneic DNA vaccine encoding for human tyrosinase as adjunctive treatment for oral malignant melanoma in dogs following surgical excision of the primary tumor. Am J Vet Res 72:1631-1638. https://doi.org/10.2460/ajvr.72.12.1631

47. Adotévi O, Mollier K, Neuveut $\mathrm{C}$ et al (2010) Targeting human telomerase reverse transcriptase with recombinant lentivector is highly effective to stimulate antitumor CD8 T-cell immunity in vivo. Blood 115:3025-3032. https://doi.org/10.1182/blood -2009-11-253641

48. Tu CF, Lin CC, Chen MC, Ko TM, Lin CM, Wang YC, Lai MD (2007) Autologous neu DNA vaccine can be as effective as xenogenic neu DNA vaccine by altering administration route. Vaccine 25:719-728. https://doi.org/10.1016/j.vaccine.2006.08.009

49. Ruan Z, Yang Z, Wang Y, Wang H, Chen Y, Shang X, Yang C, Guo S, Han J, Liang H, Wu Y (2009) DNA vaccine against tumor endothelial marker 8 inhibits tumor angiogenesis and growth. J Immunother 32:486-491. https://doi.org/10.1097/ CJI.0b013e3181a1d134

50. Olson BM, Frye TP, Johnson LE, Fong L, Knutson KL, Disis ML, McNeel DG (2010) HLA-A2-restricted T-cell epitopes specific for prostatic acid phosphatise. Cancer Immunol Immunother 59:943-953. https://doi.org/10.1007/s00262-010-0820-6

51. O'Sullivan T, Saddawi-Konefka R, Vermi W et al (2012) Cancer immunoediting by the innate immune system in the absence of adaptive immunity. J Exp Med 209:1869-1882. https://doi. org/10.1084/jem.20112738

52. Haabeth OA, Lorvik KB, Hammarström C, Donaldson IM, Haraldsen G, Bogen B, Corthay A (2011) Inflammation driven by tumour-specific Th1 cells protects against B-cell cancer. Nat Commun 2:240. https://doi.org/10.1038/ncomms1239

53. Moynihan KD, Opel CF, Szeto GL et al (2016) Eradication of large established tumors in mice by combination immunotherapy that engages innate and adaptive immune responses. Nat Med 22:1402-1410. https://doi.org/10.1038/nm.4200

54. Antony PA, Piccirillo CA, Akpinarli A et al (2005) CD8+ T cell immunity against a tumor/self-antigen is augmented by CD4+ $\mathrm{T}$ helper cells and hindered by naturally occurring $\mathrm{T}$ regulatory cells. J Immunol 174:2591-2601. https://doi.org/10.4049/jimmu nol.174.5.2591

55. van Duikeren S, Fransen MF, Redeker A, Wieles B, Platenburg G, Krebber WJ, Ossendorp F, Melief CJ, Arens R (2012) Vaccine-induced effector-memory CD8+ T cell responses predict therapeutic efficacy against tumors. J Immunol 189:3397-3403. https://doi.org/10.4049/jimmunol.1201540

56. Roomi MW, Niedzwiecki A, Rath M (2018) Peptide vaccines directed against human metalloproteinases (MMPs) with antitumor efficacy in vitro and in vivo. J Cell Med Nat Health (CM\&NH) 1

57. Obara W, Kanehira M, Katagiri T, Kato R, Kato Y, Takata R (2018) Present status and future perspective of peptide-based vaccine therapy for urological cancer. Cancer Sci 109:550-559. https://doi.org/10.1111/cas.13506

58. Takahashi N, Ohkuri T, Homma S, Ohtake J, Wakita D, Togashi Y, Nishimura T (2012) First clinical trial of cancer vaccine therapy with artificially synthesized helper/killer-hybrid epitope long peptide of MAGE-A4 cancer antigen. Cancer Sci 103:150153. https://doi.org/10.1111/j.1349-7006.2011.02106.x

59. Kavanagh B, Ko A, Venook A et al (2007) Vaccination of metastatic colorectal cancer patients with matured dendritic cells loaded with multiple major histocompatibility complex class I peptides. J Immunother 30:762-772. https://doi.org/10.1097/ CJI.0b013e318133451c

60. Parkhurst MR, Yang JC, Langan RC et al (2011) T cells targeting carcinoembryonic antigen can mediate regression of metastatic colorectal cancer but induce severe transient colitis. Mol Ther 19(3):620-626. https://doi.org/10.1038/mt.2010.272

61. Chen J, Khalil RA (2017) Matrix Metalloproteinases in normal pregnancy and preeclampsia. Prog Mol Biol Transl Sci. 148:87-165. https://doi.org/10.1016/bs.pmbts.2017.04.001

62. Matejuk A, Leng Q, Chou ST, Mixson AJ (2011) Vaccines targeting the neovasculature of tumors. Vascular Cell 3:7. https:// doi.org/10.1186/2045-824x-3-7 
63. Douglas NC, Tang H, Gomez R, Pytowski B, Hicklin DJ, Sauer CM, Zimmermann RC (2009) Vascular endothelial growth factor receptor 2 (VEGFR-2) functions to promote uterine decidual angiogenesis during early pregnancy in the mouse. Endocrinology 150:3845-3854. https://doi.org/10.1210/en.2008-1207
Publisher's Note Springer Nature remains neutral with regard to jurisdictional claims in published maps and institutional affiliations. 